\title{
SEROTONIN AND BRAIN: EVOLUTION, NEUROPLASTICITY, AND HOMEOSTASIS
}

\author{
Efrain C. Azmitia \\ Department of Biology and Psychiatry, Center for Neural Science, New York University \\ New York 10003, USA
}

\author{
I. Introduction \\ II. Evolution: From Unicellular to Humans \\ III. Holistic Brain Function Starts at Development \\ IV. Homeostasis of Brain \\ V. Clinical Implications of Loss of Homeostasis \\ References
}

Neurotransmitters are chemicals released by the presynaptic endings of neurons that have specialized actions through specific receptors on the membrane potential of postsynaptic neurons. However, these chemicals have more complex functions both within the neuron and on its varied cellular targets. These functions include changes in metabolic activities that have consequences on the plasticity of the neurons. Serotonin is an ancient chemical synthesized from an indole-containing precursor, tryptophan. A review of the evolution of this chemical within biological systems helps appreciate its holistic actions on brain homeostasis. In plants serotonin and its allied indole-containing molecules 5-hydroxytryptophan, auxin, and melatonin regulate many of the processes involved in cell differentiation: mitosis, migration, and maturation [Pasternak et al. (2005). F. Exp. Bot. 56, 1991-2001; Kolar and Machackova (2005). F. Pineal Res. 39, 333-341]. In animals, in addition to these trophic properties, 5-hydroxytryptamine (5-HT) participates in most biological functions, especially those associated with limbic and brainstem circuits. The precocious development in the center of the brainstem, its response to a plethora of stimuli and its extensive connection to all areas of the brain provide the framework for 5-HT contribution to holistic functioning of the brain. The fine anatomy of the axons and their exquisite sensitivity to environmental trophic and toxic molecules encourages the dynamics of 5-HT innervation pattern and density. The ability to modify itself by a process called neuroplasticity makes it suited to serve as a regulator in brain homeostasis, and predicts its involvement in many brain disorders, especially those concern with depression and dementia. 


\section{Introduction}

This chapter presents evidence that the neurotransmitter serotonin (5-hydroxytryptamine, 5-HT) functions as a global factor involved in brain homeostasis. The early appearance of 5-HT axons and their projections throughout the brain and spinal cord occurs prior to the differentiation of most neurons and their participation in functional circuits. The emphasis of the chapter will be on 5-HT's activation of the $5-\mathrm{HT}_{1 \mathrm{~A}}$ receptor to release the glial neurite extension factor, S100B. S100B acts to stabilize the microtubules which form the main framework of the cytoskeleton of neural cells, including neurons and astrocytes.

One of the most dynamic and pervasive neuronal systems is the brainstem raphe serotonergic neurons. The actions of 5-HT on cellular metabolism, movement, and reproduction evolved from its first appearance in aerobic unicellular organisms and plants to its current restricted neuronal localization in the brainstem of humans. In the most primitive organism, 5-HT acts within the cell to regulate cell oxidation largely due to its indole core structure, a unique ring configuration. The indole ring captures light energy and converts it to biological energy by loss of an electron (oxidation). The indole ring is now an oxidizing agent and is reduced by absorbing an electron, usually from a metal ion. The indole ring now functions as antioxidant by acting as a reducing agent that can easily lose this electron. In the cell, serotonin, melatonin, auxin, and many indole-alkaloids act as powerful antioxidants. In addition, 5-HT synthesis by the hydroxylase enzyme directly captures free oxygen and serves the important role of reducing the concentration of this reactive molecule.

In the animal kingdom, while retaining this important antioxidant and differentiating properties, 5-HT begins in crustaceans to influence higher brain functions such as dominance in a social grouping. In the human brain, the 5-HT neurons from the raphe nuclei make connections innervating the entire brain and spinal cord, which builds on its functional impact to include a link in humans to suicide.

The interactions of 5-HT neurons with neuronal and nonneuronal systems are covered with an emphasis on the diversity of the cells receiving released 5-HT: neurons, glial cells, endothelial cells, ependymal cells, and endocrine cells. The diversity of these cellular targets argues for a broad function for 5-HT in brain. The ability of 5-HT to promote brain plasticity and stabilization by acting on the cell cytoskeleton is discussed in the context of homeostasis. The important action of $5-\mathrm{HT}$ on the $5-\mathrm{HT}_{1 \mathrm{~A}}$ receptor in releasing the glial protein $\mathrm{S} 100 \mathrm{~B}$ is the basis of this regulation of morphological plasticity. The chapter, as a whole, supports the key idea expressed by Cannon in his discussion of homeostasis that "slight instability is the necessary condition for the true stability of the organism." Neuroplasticity is a necessary attribute of a homeostatic system, but 
early development and global interconnections make this system holistic in scope. The ability to change morphology, stimulate neurogenesis and differentiation, or promote cell survival is influenced by acetylcholine, catecholamines, GABA, EAAs (glutamate and glycine), and neuropeptides. However, only serotonin (5-HT) has the evolutionary and anatomical properties to serve as a global regulator unifying the whole brain into a cohesive biological system.

\section{Evolution: From Unicellular to Humans}

A delay in our appreciation of the diverse actions of neurotransmitters was the focus on electrophysiology which dominated the study of the brain in the early twentieth century. The chemical substances released by neurons were considered to be mediators of the electrical current across the synapse, thus the word "neurotransmitters." The focus of many early neuroscience studies in the twentieth century was to determine if neurotransmitters were excitatory or inhibitory electrical influences on the membrane potentials of postsynaptic cells. Neurotransmitters by acting on specific receptors were considered to be ionotrophes capable of opening specific ion channels. They traveled in fixed circuits and the notion of neurons and synapses being plastic was not considered until late in the 1950s (Liu and Chambers, 1958).

The reality of the situation is "neurotransmitters" predate the formation of nervous tissue. Serotonin is found in all animals, plants, and most unicellular organisms (Garattini and Valzelli, 1965). It is synthesized from the amino acid tryptophan by the action of two enzymes, tryptophan hydroxylase, and aromatic amino acid decarboxylase (Fig. 1). Tryptophan is synthesized by a variety of enzymes (Zhao and Last, 1996). The creation of the indole structure served an important function in the start of aerobic life on the earth. The conversion of energy (photons) derived from the sun into biological energy requires capturing a light wave and the loss of an electron. Interestingly, the indole ring is the most efficient molecule for doing exactly this and most sensitive to blue light (450 nm) (Borkman and Lerman, 1978). Most proteins are endowed with an intrinsic UV fluorescence because they contain aromatic amino acids, specifically phenylalanine, histamine, tyrosine, and tryptophan. Of these aromatic amino acids, tryptophan has the highest fluorescence quantum yield overshadowing markedly the emissions of the other two. Tryptophan emission maxima in proteins can vary from 332 to $342 \mathrm{~nm}$ depending on the protein. Free tryptophan has a characteristic fluorescence emission at 350-360 nm (Borkman and Lerman, 1978). Absorption of blue light waves is able to excite the indole structure so that it loses one of the electrons from its indole ring structure, it becomes oxidized. This single electron begins a directed journey jumping from heavy metals to 


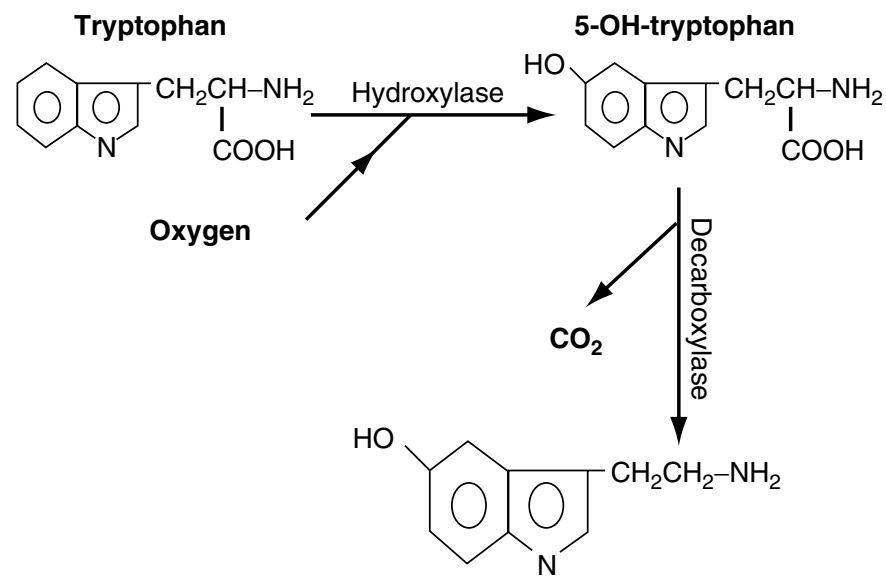

\section{Serotonin (5-HT)}

Fig. 1. The synthesis of serotonin from tryptophan involves two enzymes, tryptophan hydroxylase and aromatic amino acid decarboxylase.

finally produce reduced chemical cofactors, such as NADH and NADPH, and generates $\mathrm{O}_{2}$ from $\mathrm{H}_{2} \mathrm{O}$ as a by-product. The production of $\mathrm{O}_{2}$ is the most relevant for life on the earth, since our atmosphere on the earth contains $20 \%$ oxygen, and supports all aerobic organisms. Tryptophan's ability to capture light is used by nearly all proteins (e.g., chlorophyll, rhodopsin, and skin pigment cells) which capture light and convert it to biological energy (Angiolillo and Vanderkooi, 1996). These proteins have tryptophan as the core amino acid for their function. Cells such as blue-green algae, molds, and plants became very adept at producing oxygen. A critical problem developed in these cells: What to do with all the reactive oxidizing agents produced during the generation of oxygen?

One of the solutions for dealing with excess oxidation was to use the biological machinery employed before $\mathrm{O}_{2}$ was available, and the atmosphere was nearly all $\mathrm{CO}_{2}$. Anaerobic cells had developed a variety of enzymes for converting $\mathrm{CO}_{2}$ into biological energy in the form of glucose. The most common process was to produce the sugar, glyceraldehyde- 3 phosphate, a three-carbon sugar produced by three molecules of $\mathrm{CO}_{2}$. The first enzymatic step in this reaction involves the attachment of a molecule of $\mathrm{CO}_{2}$ to the five-carbon sugar, ribulose bisphosphate $(\mathrm{RuBP})$. The reason this step is emphasized is that the enzyme which catalyzes this initial reaction, and possibly the most abundant enzyme on the earth, is RuBP carboxylase, also known as rubisco. The carboxylase at the very early stages of life on the earth primarily attached to $\mathrm{CO}_{2}$, however as $\mathrm{O}_{2}$ levels increased it was shown that this compound could react 
more favorably with oxygen (Smith, 1976). This was the first enzyme to attach oxygen to a substrate [such as tryptophan to produce 5-hydroxytryptophan (5-HTP)], a process termed hydroxylase because only a single oxygen is used and the other forms water. Furthermore, RuBP carboxylase has the same phosphate-binding site sequence found in tryptophan biosynthetic enzymes (Wilmanns et al., 1991).

The substrates for the primitive hydroxylase enzyme were tryptophan, tyrosine, and phenylalanine, all of which can capture light (Boularand et al., 1998; Grenett et al., 1987; Wiens et al., 1998). The hydroxylase enzyme gave rise to a very large number of complex alkaloids in plants, all of which are potent antioxidants in their own right. As we now know, cellular oxidation is important for cell maturation and division, but excess oxidation results in cell death. The synthesis of pharmaceutically important monoterpenoid indole involves the hydroxylase as well as decarboxylase enzymes (Facchini et al., 2000). 5-HTP, the immediate precursor of serotonin, is formed from tryptophan hydroxylase. This molecule is rapidly converted to serotonin by the ubiquitous working in reverse to function as a decarboxylase. Thus, serotonin is produced from tryptophan by enzymes commonly used in anaerobic organisms before $\mathrm{O}_{2}$ was formed inside cells. Besides the algae, fungi, and molds, the most efficient generator of $\mathrm{O}_{2}$ and serotonin is plants. The levels of serotonin inside plants far exceed those seen in the animal brain by $100 \times$; banana skin $(40 \mu \mathrm{g} / \mathrm{g})$ versus rat hippocampus $(0.4 \mu \mathrm{g} / \mathrm{g})$ (Garattini and Valzelli, 1965; Sparks and Slevin, 1985). Interestingly, the immediate precursor of 5-HT, 5-HTP accounts for $20 \%$ of the total fresh weight in seeds from Griffonia simplicifolia, a tropical shrub of west Africa, which has potent medicinal properties (Lemaire and Adosraku, 2002).

Tryptophan was always a key to life because of its ability to convert solar energy into biological energy. The consequence of this process made tryptophan and its associated molecules involved in all aspects of the organism's life: mitosis, movement, and maturation. As oxygen began to be a major component of the atmosphere of the earth, enzymes that served a central function in conversion of $\mathrm{CO}_{2}$ into glucose now evolved to hydroxylate many substrates. Hydroxylation leads to 5-HTP and 5-HT as well as to many indole alkaloids used for medicinal purposes today (Fig. 1).

A closer look at plants provides evidence that serotonin and its products, such as melatonin and auxin, serve crucial actions in the life and organization of plants. Plants are complex, multicellular organisms that have specialized cells that function as a unit, a holistic organization. Plants evolved a specialized intracellular organelle, the chloroplast, not only to capture light, but also as the source of tryptophan synthesis. All the enzymes for making tryptophan were localized in these specialized organelles and could only be converted into their mature form when inside the chloroplast (Zhao and Last, 1996). Plants are extremely efficient at capturing light because they were extremely efficient at making tryptophan. 
Plants do not have neurons or muscles, but they are nevertheless capable of limited movement by rotating their leaves toward light and sending their roots deep into the soil to capture $\mathrm{H}_{2} \mathrm{O}$ and nitrogen. Both the movements of leaves and roots depend on compounds similar to serotonin such as auxin (Ivanchenko et al., 2006). Auxin and other tryptophan derived compounds are transported inside the plant cells and regulate the fast tracing of leaves toward the shifting source of light. The turning of the leaf to its source of energy depends on the rearrangement of the cells cytoskeleton inside the leaf cells. In the root, the emersion into the soil is produced by regulating cell division and maturation. These two forms of producing movement, mitosis, and maturation of plant cells are similar to that seen in unicellular organisms and fungi (Eckert et al., 1999). The actions of serotonin on the cell cytoskeleton and differentiation forecast the actions of serotonin in neuronal development and adult neuroplasticity in mammals (Azmitia, 1999). Receptors for serotonin and other "neurotransmitters" are found in plants. One can assume that receptors are a necessary component for the integration of specialized cells in a multicellular organism, and it appears that their action is concerned with the coordinating metabolic processes.

Animal cells lack chloroplast, an organelle so central to plant photosynthesis and tryptophan synthesis. This lack of a key evolutionary mechanism of life promoted animals to develop a number of traits in order to survive. Animals had to move to capture organism that contained tryptophan and develop specialized cells for extracting $\mathrm{O}_{2}$ from the atmosphere. 5-HT- and 5-hydroxytryptaminederived alkaloids are found in sponges, the most primitive form of animal life (Salmoun et al., 2002). This specie does not have a nervous system and feeds by filtration. In hydra, the most primitive animal with a specialized nervous and motor system, 5-HT appears to be localized to sensory cells scattered along the epithelium of the organism (Fig. 2). When 5-HT is applied to hydrazan larvae, the animal undergoes a pronounced metamorphosis in which it develops a variety of specialized cells involved in feeding and movement (McCauley, 1997). This maturation process is triggered by 5-HT release and a receptor action that has protein kinase $\mathrm{C}(\mathrm{PKC})$ in its pathway and is blocked by both ketanserine and clozapine. These steps and inhibitors act on human 5-HT receptors (Azmitia, 2001a). When a distinct nervous system is seen, such as in the flatworm (S leucops), serotonin neurons are localized there (Wikgren and Reuter, 1985).

Serotonin in animals is produced in very low quantities because of the limitation of tryptophan and this may explain the very few cells that contain 5-HT. As seen in hydra and flatworms, these specialized 5-HT cells are nevertheless ideally localized and have pronounced actions on the life of the organism. As these organisms evolved a neuronal center for responding to their complex environment, serotonin continues to serve a key part. In Aplysia, there is a primitive brain with only a few rudimentary behaviors mainly concerned with 

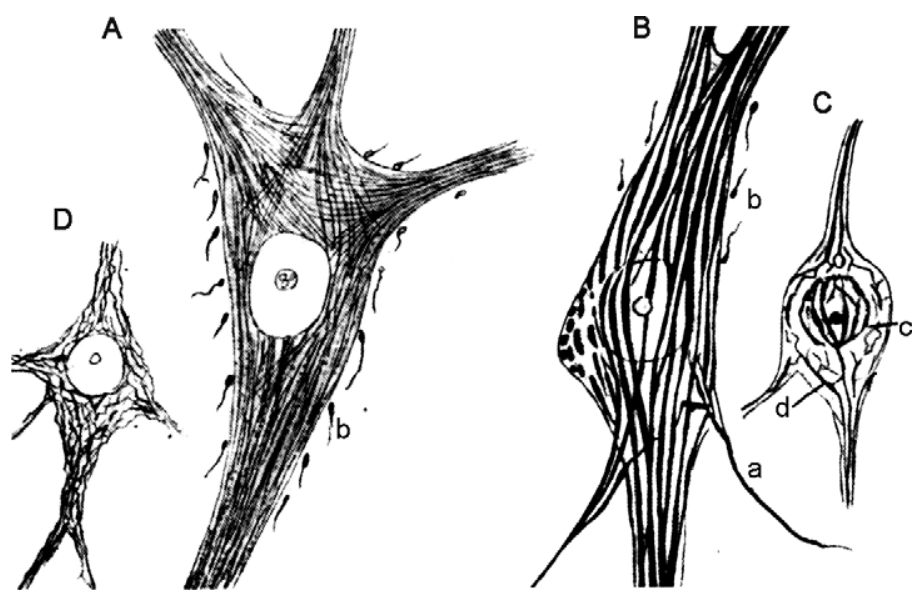

FIG. 2. Cells of lizard spinal cord; illustration demonstrates the changes in neurofibrillar network according to season and temperature. Cajal (1899) used the reduced silver nitrate method. (A and D) Cells of lizard kept in warm or cold for several hours. (B and C) Cells of a lizard in a state of hibernation in lizards. He observed not only was the neuron smaller in size and branching, but there were also fewer connections on its surface.

movement, eating, defense, and reproduction (Marois and Carew, 1997). "The results indicate that the first serotonergic cells emerge at mid-embryogenesis and that a total of five cells make up the entire serotonergic system by hatching. These cells are part of a newly discovered ganglion in Aplysia, called the apical ganglion." The serotonin released from these neurons interacts with specific receptors to increase or decrease the firing rate of its target cells involved in sensory and motor processing. In addition, serotonin changes cAMP and $\mathrm{Ca}^{2+}$ levels in its target neurons and influences their transcription rate and modifies cell morphology (Pettigrew et al., 2005). The changes in neuronal morphology are particularly intriguing because they affect neuronal connectivity (Glanzman et al., 1990). 5-HT by increasing cAMP and P-CREB mediates a trophic response that may underlie both maturation and memory formation in this lower animal. Thus, in much the same way as serotonin and its derivatives influence the process and organelles of photosynthesis to move in order to tract the source of light, in animals serotonin influences the morphology of sensory and motor neurons involved in neuronal networking in order to tract the source of relevant stimuli.

As we continue to ascend the animal kingdom, the synthesis of serotonin remains restricted to a few cell types (e.g., mast cells and neurons), involved in promoting differentiation and regulating many key biological functions. Serotonin-producing cells served a defense mechanism (stinging) in coelenterates and in many insects (Horen, 1972; Weiger, 1997). Actions of serotonin on sexual 
activity and reproduction are seen in Nematodes (Boyle and Yoshino, 2005). In lower animals, serotonin neurons are primarily sensory neurons (activated by external stimuli) and influence food intake, defense withdrawal, and complex locomotor behaviors such as swimming (e.g., in sea urchins, Yaguchi and Katow, 2003). In the ganglia of Annelids, serotonin is first found in interneurons, which permits better regulation of complex behaviors such as swimming (Kristan and Nusbaum, 1982) and possibly learning and memory (Moss et al., 2005). In Caenorhabditis elegans, 5-HT is involved in modulating feeding behavior by rapidly altering a chemosensory circuit (Chao et al., 2004). Serotonin in arthropods (lobsters) regulates socially relevant behaviors such as dominancetype posture, offensive tail flicks, and escape responses (Kravitz, 2000). The actions of serotonin thus extend from those of antioxidant through morphogenesis and ascend to being involved in complex behaviors such as position in a social hierarchy. 5-HT-regulated social and mental behaviors increased in number and complexity in vertebrates. In these higher animals, 5-HT continued in its role of a homeostastic regulator in adjusting the dynamic interactions of these many functions.

\section{Holistic Brain Function Starts at Development}

A few cells in the body are serotonergic, expressing the enzymes tryptophan hydroxylase, aromatic amino acid decarboylase, 5-HT transporter (5-HTT), and the $5-\mathrm{HT}_{1 \mathrm{~A}}$ receptor. These are found in the brainstem, in the enteric nervous system, and in mast cells scattered throughout the body. Serotonin influences cells in all stages of development and in all organs. In the human brain, serotonin neurons are more numerous $(>250,000)$ than in other species and form a tight, small cluster along the midline of the brainstem (Tork, 1990). The projections from these clusters are more restricted than the diffuse projections seen in rodents (Fig. 3). The axons in rats and mice are predominately thin, highly branched, and unmyelinated. In primates, highly myelinated fibers are common compared to the rodents where they are rare (Azmitia and Gannon, 1983) (Fig. 4). Thus, the organization of the serotonin neurons is more evolved in the primate. In Aplysia, a few giant cells contain serotonin, and these cells have dense projections to both sensory and motor centers. In rodents, serotonergic neurons act by mass action, with large number of neurons acting in concert. In the primate brain, the serotonergic cell bodies collect into small clusters and appear to have established more discrete target.

The overall function of serotonin is fairly similar in vertebrates with most biological processes (movement, breathing, reproduction, and temperature regulation) under the strong influence of serotonin. The activity of brainstem serotonergic 


\section{Ectoderm}

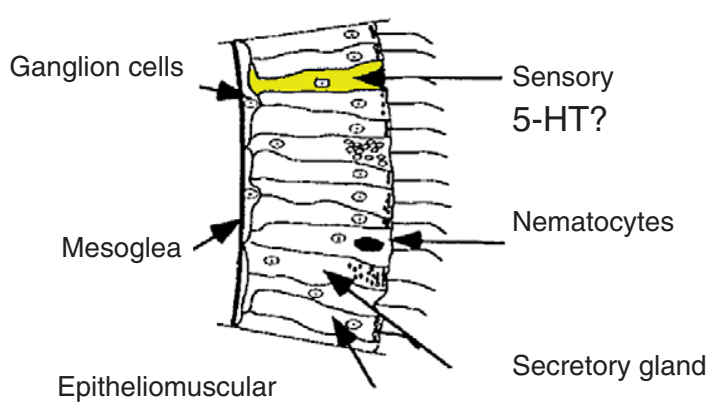

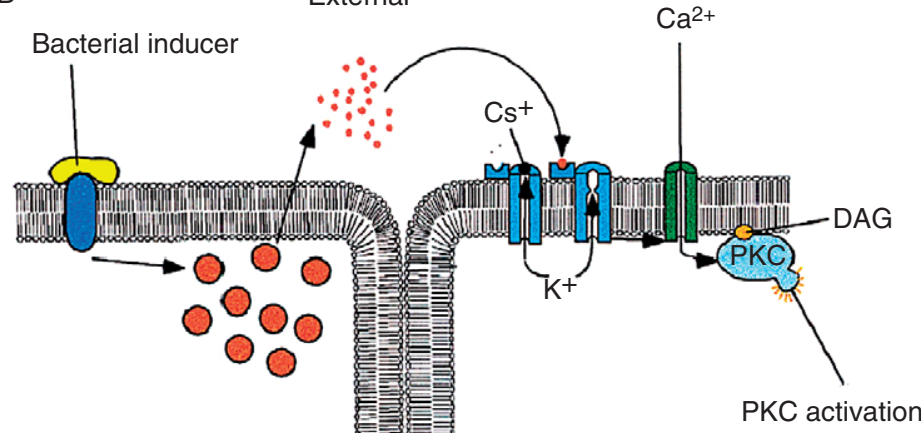

5-HT- containing cell

5-HT target cell

FIG. 3. Proposed 5-HT action in hydra nervous system (modified from McCauley, 1997). 


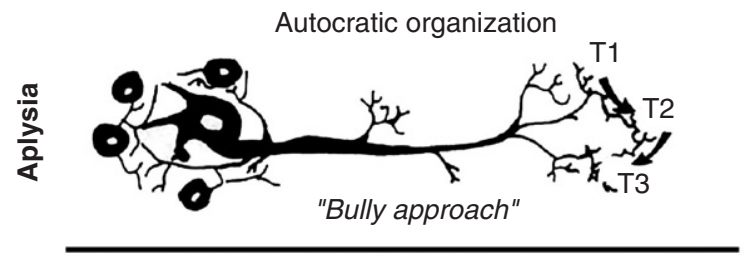

Committee organization
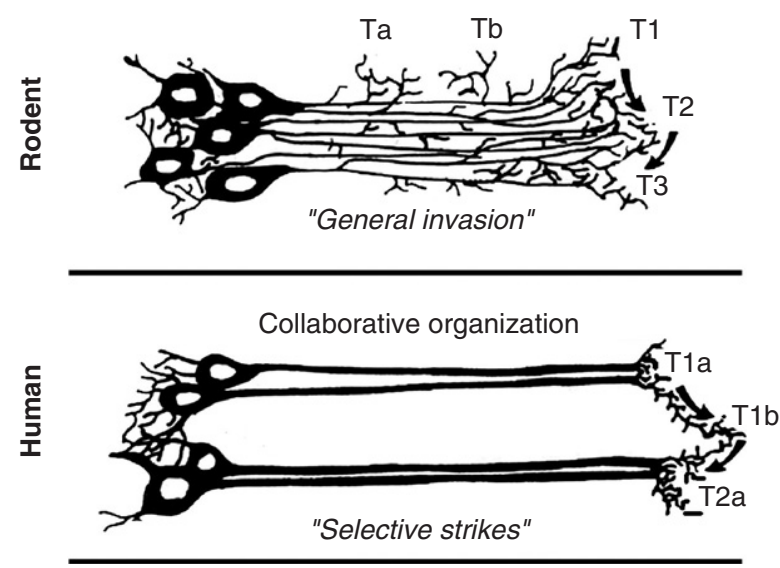

FIG. 4. The progression of 5-HT neurons from Aplysia to humans (Azmitia, 1987).

neurons in rodents and cats has a slow and rhythmic pattern of firing. This pattern produces a constant release of serotonin, ideally suited for the distribution of a trophic molecule rather than a neurotransmitter system involved in point-to-point rapid activity (Jacobs and Azmitia, 1992). In higher animals, serotonin continues to be involved in many behavioral activities, including aggression, sleeping, eating, locomotor activity, attention, learning, memory, sensitization, and sexual activity. It also regulates physiological mechanism such as temperature, feeding, respiration, blood flow and clotting, osmolarity, and hormone secretion. These functions act in concert and there combined function can be described as holistic.

The organization of the 5-HT neurons in the human brain has been extensively reviewed (Azmitia, 1978; Jacobs and Azmitia, 1992; Parent, 1981; Tork, 1990) (Fig. 4). Initially, there are two large groups of serotonergic neurons which appear early in development. The serotonergic phenotypic is induced by the external transcription spacer, Pet-1 (Hendricks et al., 1999). Pet-1 is regulated by the LIM homeodomain and the transcription factors Mashi and Gata-2, after the functional loss of the Nkx2.2 homeodomain. Pet-1 in turn is the transcription factor for $5-\mathrm{HT}_{1 \mathrm{~A}}$ receptor, tryptophan hydroxylase, and the 5-HTT which are 
expressed around gestational day $12-14$ in the mouse brain (first trimester in humans). The two distinct groups of 5-HT neurons appear to have distinct maturational and migrational patterns (Lidov and Molliver, 1982; Wallace and Lauder, 1983). The anterior group (DRM, dosal raphe nucleus; CSD, centralis superior nucleus, pars dorsalis; CSM, centralis superior nucleus pars medianus, supraleminiscal nucleus) projects predominately rostrally to the forebrain, thalamus, and hypothalamus, while the caudal group (RO, nucleus raphe obscurus; NRPa, nucleus raphe pallidus; RM, nucleus raphe magnus; VR, nucleus raphe ventricularis) projects caudally and ventrally to innervate the spinal cord and cerebellum, respectively.

Besides having a number of similar proteins under the control of Pet-1, the various 5-HT neurons share a similar neuronal appearance (large soma, multipolar shape, and largely unmyelinated, highly varicose thin axons) (Cajal, 1899; Scheibel et al., 1975; Steinbusch, 1981). The dendrites from these neurons have spines and are associated with blood vessels and glial cells (Azmitia, 1978). The axons show a propensity to follow myelinated fiber tracts in order to innervate a wide variety of targets by a process termed epiphytic guidance (Azmitia, 1978). Both the dendrites and axons are seen crossing the ependymal layer to enter and exit from the ventricular system. The neurons share a distinct firing pattern which is high during the day when the animals are mobile and very slow at night when the animals are sleeping (Jacobs and Azmitia, 1992). The raphe neurons are sensitive to glucose, $\mathrm{pH}$, blood $\mathrm{CO}_{2}$ and $\mathrm{O}_{2}$, and body temperature (Azmitia, 1999; Severson et al., 2003). The serotonergic neurons not only affect the morphology of neurons, but also glial cells (Chang et al., 2005).

Most functions attributed to serotonin have centered on its effects on specific neurons and distinct receptors. For example, electrophysiological studies indicate these neurons are all sensitive to $\mathrm{CO}_{2}$ (Severson et al., 2003) and may participate in the process of respiration, and correlate with behavioral arousal and may participate in motor activity (Jacobs and Azmitia, 1992). Sensitivity to $\mathrm{CO}_{2}$ and behavioral arousal can be interpreted to be homeostatic, but not holistic. The next discrete function for serotonin neurons was their involvement in respiration. Using Golgi-stained brainstem material, a close relationship is seen between the raphe reticular neurons and blood vessels. Scheibel et al. (1975) wrote nearly three decades ago after they found raphe neurons in contact with blood vessels:

A chemosensitive role for these raphe elements represents a reasonable extension of putative reticular function. Proactive evidence already available suggests that some brain stem neurons may be sensitive to blood $\mathrm{CO}_{2}$ levels, and to the osmolarity of the circulating medium. Indeed, it is conceivable that raphe neurons themselves may be sensitive to one or another of these ... given their intimate neurovascular position and their apparent obligatory role in the onset of sleep, they may be capable of detecting circulating substances such as plasma cortisol and ACTH, etc., whose concentrations are time-locked to circadian rhythms and possibly to the shorter rest-activity cycle of Kleitman. 
More recently, carbon dioxide chemoreceptors were found in both the medullary and midbrain raphe serotoninergic neurons (Severson et al., 2003). Previously, these chemosensitive cells were believed to be confined to the medulla. This finding is reminiscent of the diurnal rhythm in raphe firing (Jacobs and Azmitia, 1992). The cells contain similar transcription factors to make, release, and detect serotonin (Hendricks et al., 1999) and the fetal innervation of common targets in spinal cord and hippocampus (Azmitia and Whitaker-Azmitia, 1987). Severson et al. (2003) suggest their results are relevant to sudden infant death syndrome (SIDS), panic disorder, and migraine headaches. They write that "despite a tendency to study these neurons in relation to only a shared brain function or disease, their highly divergent projections and the homogeneity of their cellular properties (Jacobs and Azmitia, 1992) suggest that there may be a shared function of serotonergic neurons." These studies show a similar function of the midbrain and medullary raphe neurons although these cells develop in different areas of the brainstem, as the rostral and caudal groups seen at gestational day 14 (Scott et al., 2005; Wallace and Lauder, 1983). These shared structural, metabolic, developmental, anatomical, and functional characteristics suggest the raphe neurons, whether located in the midbrain, pons, or medulla, share a holistic action on brain function, irreducible to the sum of its parts (Azmitia, 2004).

\section{Homeostasis of Brain}

Historically, many scientists have proposed general (holistic?) functions for serotonin. Brodie and Shore (1957) proposed a holistic metabolic role for serotonin in the neuronal activity of the brain. In their hypothesis, norepinephrine and serotonin modulated opposite systems in the brain based on Hess's (1954) concept of the functional integration of the autonomic system with the central nervous system (CNS). Serotonin was the modulator of the trophotrophic system, which integrates behavioral patterns that are recuperative in nature. This was considered a recessive system, which normally functions during sleep or hibernation. This idea was similar in nature to Cajal's view that sleep represented a time of neuronal rest characterized by a withdrawing of the neuronal connections. This idea comes close to a holistic regulator, the metabolic control may be consistent with a neurotrophic role for 5-HT and NE, and their interactions can be viewed as homeostatic in nature. However, the framework for this system was faulty. Serotonin was considered to function during sleep, although the firing rate of the raphe nuclei is silent during sleep. Furthermore, Brodie and Shore supposed the main interactions were between neurons, and failed to acknowledge the role of nonneuronal cells: glial, ependymal, endothelial, and hormonal. Despite these shortcomings, which mainly reflect the state of neuroscience in 1957, 
the theories of Brodie and Shore are worth revisiting. A few years after Brodie and Shore (1957), serotonin alone was proposed to be essential for normal mental health (Woolley, 1961). This hypothesis was based on its similar structure to d-lysergic acid diethylamide (LSD), discussed more fully by Whitaker-Azmitia (1999). This idea was not well received and most current mental health professionals do not consider mental health to be a holistic disorder. Mental disorders are thought to be a local dysfunction due to a specific deficit, such as reduced levels of dopamine or serotonin, in a localized region of the brain such as the hippocampus, prefrontal cortex, or cingulate.

We now propose that the globally projecting raphe neurons have the anatomical and functional characteristics to coordinate the physiology of the whole brain. Although specific actions of 5-HT are local, nevertheless the scope is global. The disruption of one group of raphe neurons impacts the system as a whole. The role of 5-HT as an integrating component of neural tissue emphasizes the importance of neuroplasticity. 5-HT neurons show morphological and functional responses to a variety of neuronal and nonneuronal factors. The dynamic view of a plastic 5-HT brainstem system with neurotrophic actions encompasses the concepts of Woolley (1961), Brodie and Shore (1957), and Severson et al. (2003). The serotonin neurons evolved from plants as general regulatory system which responds to external stimuli to produce structural changes to meet those signals, be they the source of light or temperature. The system modifies itself to achieve the instability needed for homeostasis. This function of serotonin can be observed in plants and unicellular organisms, long before the advent of neurons. The fluctuations in serotonin levels are broadcast throughout the brain and serve to dynamically integrate and stabilize CNS structure and function. In a previous paper, we introduced the concept that 5-HT raphe neurons might participate in the process of brain homeostasis. The maintenance of a stable nervous system in a dynamic environment is certainly a holistic function since it is difficult to imagine this process being a sum of its component parts. Homeostasis implies not only stability of a given set point or function, but more importantly the dynamic equilibrium seen around that set point.

Proposing 5-HT raphe neurons are involved in homeostasis may be considered a truism, but there are certain implications of this statement that make it interesting to consider. First, a homeostatic regulator needs to sense all the pertinent variables necessary to achieve and maintain an equilibrium. The 5-HT distribution in the brain reaches all areas and includes target cells in the vascular, neuronal, and endocrine systems. The function of 5-HT neurons serves to integrate all cell types in all areas of the brain. The global framework serves to receive and integrate the varied pertinent variables into a holistic unit (Fig. 5). Second, a homeostatic regulator needs to adjust the activity and architecture of the systems involved in equilibrium. 5-HT neurons can produce rapid changes in postsynaptic neuronal firing, glial activity, blood flow, breathing, temperature, 


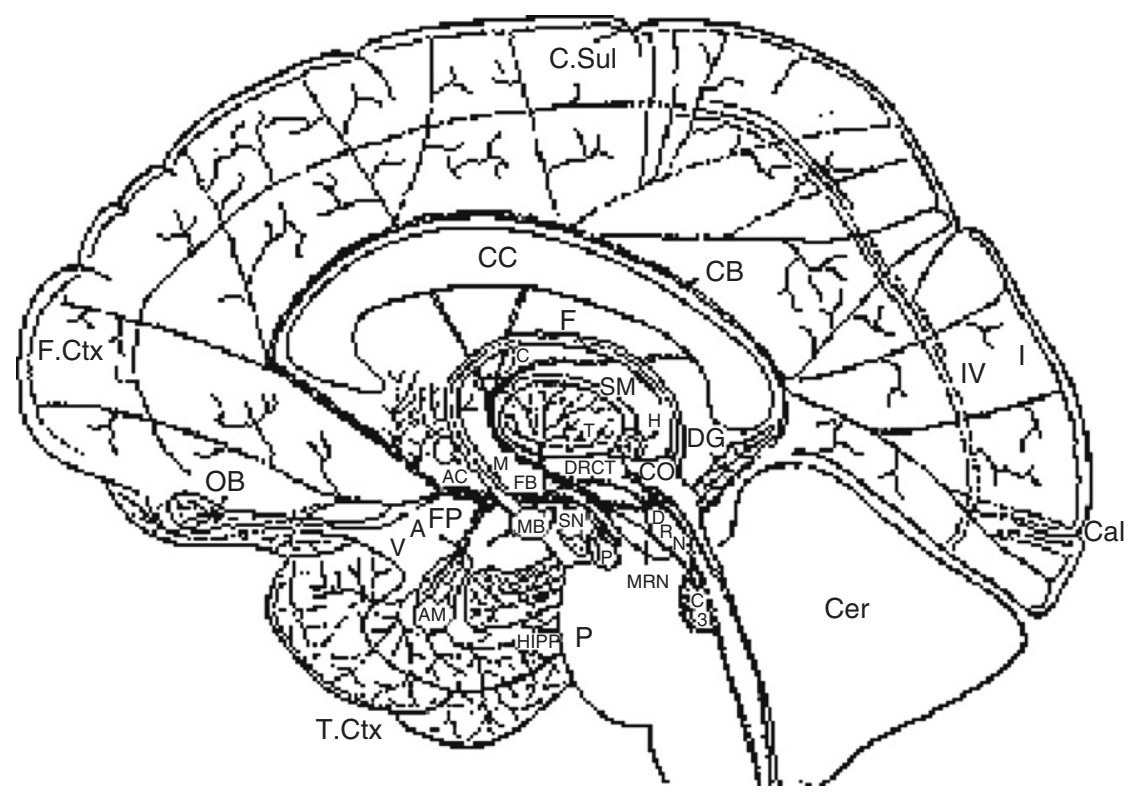

FIG. 5. The 5-HT projections in the human brain (modified from Azmitia and Gannon, 1986).

and hormonal secretion. 5-HT promotes cellular mitosis, migration and maturation of neurons and glial cells, and change how these cellular systems interact. Third, a homeostatic regulator should be able to adjust its own set point to accommodate changes in input to more efficiently reduce fluctuations. 5-HT neurons modify their own cellular architecture in response not only to sensory neuronal inputs, but also to glial cells (Azmitia et al., 1990; Nishi et al., 2000), hormonal levels (Azmitia et al., 1993; Chamas et al., 2004; Cordero et al., 2001), neuropeptides (Davila-Garcia and Azmitia, 1990), and glucose (Martin-Cora et al., 2002). Some of the effects of nutrition can be directly traced to the supply of the essential amino acid tryptophan. "These relationships between precursor availability from the periphery and brain neurotransmitter synthesis may ultimately provide the brain with information about peripheral metabolic state" (Fernstrom, 1977).

The ability to change activity and shape in response to external factors has important implications with respect to homeostasis. It is interesting to quote Professor Walter Cannon, who first elucidated the concept of "fight or flight," and whose research on the PNS and neurotransmission led to the concept of homeostasis. "By an apparent contradiction, it maintains its stability only if it is excitable and capable of modifying itself according to external stimuli, and adjusting its response to the stimulation. In a sense it is stable because it is 
modifiable - the slight instability is the necessary condition for the true stability of the organism" (Cannon, 1929). We coined the phrase neuronal instability to refer to the tendencies of neuronal cytoskeleton to shrink in the absence of stabilizing molecules such as S100B and glucocorticoids (Azmitia, 2002; Azmitia and Liao, 1994). The morphology of granule neurons in the adult hippocampus decreased when circulating glucocorticoids were removed (Liao et al., 1993). This could be seen by measuring the size of the dentate gyrus and was accompanied by a loss of $5-\mathrm{HT}_{1 \mathrm{~A}}$ receptor mRNA.

The $5-\mathrm{HT}_{1 \mathrm{~A}}$ receptor is an ancient molecule, estimated to be about 800 million years old (Peroutka and Howell, 1994). This is an intronless receptor protein that was mentioned earlier as being induced by PET-1, an external transcription spacer seen in 5-HT neurons prior to their phenotypic differentiation. Thus, the loss of granule neuronal phenotype and $5-\mathrm{HT}_{1 \mathrm{~A}}$ receptor $\mathrm{mRNA}$ may be molecularly and evolutionarily linked. The very early developmental expression of the $5-\mathrm{HT}_{1 \mathrm{~A}}$ receptor protein mRNA is seen at fetal day 15 in the rat (Hillion et al., 1993). At this very early period, which is prior to neuronal differentiation in most of the forebrain, the levels of the $5-\mathrm{HT}_{1 \mathrm{~A}}$ receptor $\mathrm{mRNA}$ are higher than at any other time in the life of the animal. In the immature cerebellum of the rat, the $5-\mathrm{HT}_{1 \mathrm{~A}}$ receptor protein expression is seen on neurons and astrocytes (Matthiessen et al., 1992). A similar, but lower, glial expression of the $5-\mathrm{HT}_{1 \mathrm{~A}}$ receptor protein was seen in the adult hippocampus (Whitaker-Azmitia et al., 1993). What is the significance of this early expression, and why on both neurons and glial cells?

The action of astrocytes on neuronal survival and differentiation is complex. First, cortical neuronal precursors are believed to form from radial glial cells and astrocytes during early development (Alvarez-Buylla et al., 2001). The astrocytes provide glucose from stored glycogen, a process under the control of the $5-\mathrm{HT}_{2 \mathrm{~A}}$ receptor (Azmitia, 2001a). Glial cells release protein factors involved in neuronal survival (e.g., NGF), attachment (e.g., laminin), and extension (e.g., S100B). These cells contain many different neurotransmitter receptors to control the availability of these factors, and the $5-\mathrm{HT}_{1 \mathrm{~A}}$ receptor is particularly related to S100B release (Ahlemeyer et al., 2000; Eriksen et al., 2002; Whitaker-Azmitia et al., 1990) (Fig. 6). S100B is a neurite extension factor (Azmitia et al., 1990; Kligman and Marshak, 1985). The ability to promote neurite extension is attributed to its ability to prevent the phosphorylation of MAP proteins by PKC (Baudier and Cole, 1988; Sheu et al., 1994). This is an MAP-specific inhibition since S100B does not inhibit PKC phosphorylation of histones (Sheu et al., 1994) and may be related to the ability of S100B to directly interact with MAPs (Donato et al., 1989). The route from the astrocytes where S100B is made to interact with the neuronal cytoskeleton may involve the receptor for advanced glycation endproducts (RAGE) (Hofmann et al., 1999; Rong et al., 2005). RAGE can translocate extracellular S100 into human endothelial cells (Hsieh et al., 2004), 


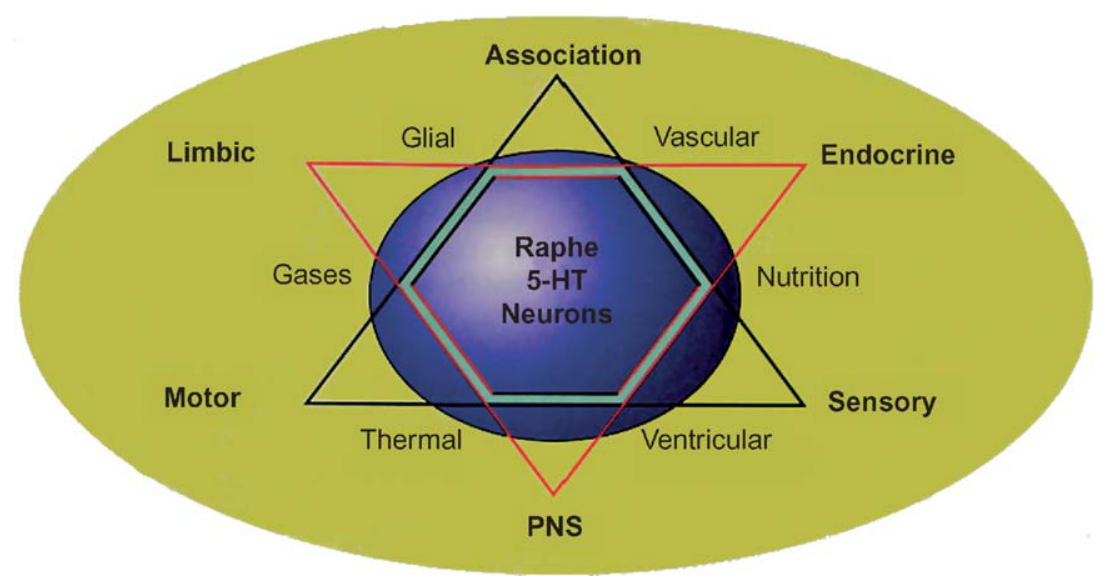

FIG. 6. A schematic representation of 5-HT raphe neuronal interactions with the key systems of the brain (modified from Azmitia, 1999).

and we can assume a similar translocation occurs with neurons that have the RAGE receptor. Interestingly, AGE molecules that are elevated in diabetes block this translocation.

The interactions between the $5-\mathrm{HT}_{1 \mathrm{~A}}$ receptor and $\mathrm{S} 100 \mathrm{~B}$ thus provide the mechanism for modifying not only the serotonergic neurons themselves but the neurons throughout the brain. The first to show a 5-HT-induced loss of target cell morphology were the late Dr. Okado and his students (Okado et al., 1993). $p$-chlorophenylalanine (PCPA) a serotonin synthesis inhibitor was given to adult chicks for 1 week, and the nonserotonergic axodendritic synapses in the cortex were shown to be dramatically reduced. When the studies were repeated in adult rats, the number of synapses in the hippocampus was significantly reduced and the animals showed memory loss (Matsukawa et al., 1997). 5-HT loss by either PCPA or para-chlorophenylalanine produced loss of neuronal dendrites and terminals in adult rat brains (Azmitia et al., 1995; Whitaker-Azmitia et al., 1995), and the injection of a $5-\mathrm{HT}_{1 \mathrm{~A}}$ receptor agonist reversed these losses (Azmitia et al., 1995). The loss of the target morphology not only was reversed by injections of the $5-\mathrm{HT}_{1 \mathrm{~A}}$ agonist, but was shown to involve the glial protein S100B (Eriksen and Druse, 2001; Wilson et al., 1998). These and other changes in adult morphology indicate that 5-HT has a central function in regulating the morphology of adult neurons, either by increasing S100B or by direct action of the 5-HT $\mathrm{HA}_{1 \mathrm{~A}}$ receptor (Azmitia, 2001b). Furthermore, the strong actions of 5-HT during development indicates these trophic actions of serotonin are present at birth and persist throughout life (Mazer et al., 1997; Whitaker-Azmitia, 2005). 


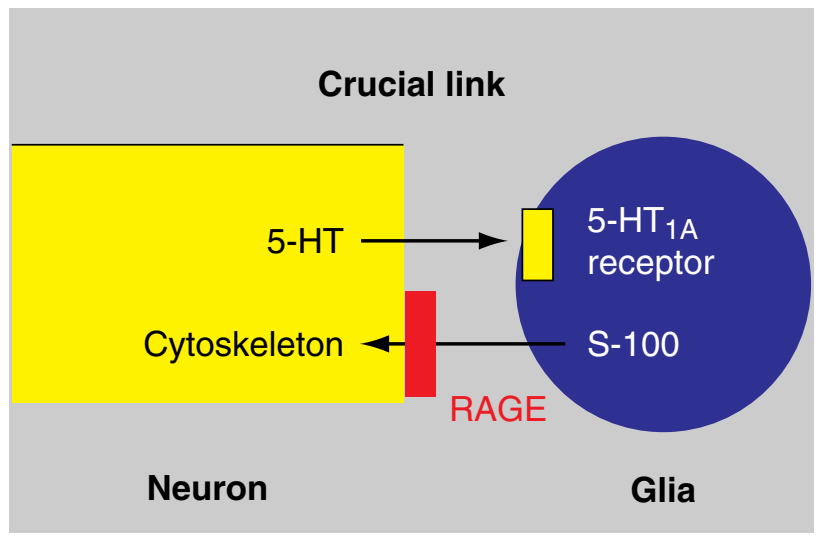

FIG. 7. A schematic showing the relationship between 5-HT neurons and glial cells.

Cannon said: "In a sense it is stable because it is modifiable." Thus, if 5-HT is directly involved in regulating homeostasis of the brain, it produces stability because it functions to release $\mathrm{S} 100 \mathrm{~B}$ and is also regulated by it (Fig. 7). The direct receptor-mediated stability from $5-\mathrm{HT}_{1 \mathrm{~A}}$ receptor inhibition of $\mathrm{C}$-AMP is developed in a previous review (Azmitia, 1999). 5-HT, as mentioned earlier, is found in all plants and animals. 5-HT from maternal blood begins to bathe the developing fetus from conception, providing a very early start to its functioning as a homeostatic regulator in the dynamic emerging connections of the brain. But what happens when 5-HT is lost? Short-term decreases in 5-HT occur almost every night when we sleep and muscle movement is inhibited (Trulson and Jacobs, 1979). This is consistent with the notion that neuronal connections are unstable and labile during sleep, an idea supported by Cajal that is over 100 years old (Azmitia, 2002). Since serotonin levels fluctuate over the year (Singh, 1964; Wirz-Justice et al., 1977), we can expect, although it has not been shown, that the capacity for learning and memory may show a similar fluctuation. What has been shown to fluctuate is the incidence of suicides (Bjorksten et al., 2005; Dreyer, 1959).

\section{Clinical Implications of Loss of Homeostasis}

Selye (1956) proposed a unified theory to explain why stress, and a corresponding loss of homeostasis, could impair general health. A few years later, Wooley (1962) suggested a more specific hypothesis that serotonin was the 
principle factor involved in regulating mental health. His theory was based on his work with serotonin and LSD. He had shown a strong structural similarity between serotonin and LSD, despite the fact he was blind. He also was the first to show that serotonin and LSD both had similar functions in the brain. It is intriguing that Dr. Woolley considered that a single chemical could assume a function so large, so important, as regulating mental health. He did not write of neuroplasticity nor of homeostasis, but his scope was certainly holistic. If 5-HT is a regulator of homeostasis, then a dysfunction of serotonin should have major consequences. One consequence of lowered serotonin is depression. Suicide, the act of an individual voluntarily ending his or her own life, is the ultimate rejection of the evolutionary drive to survive. In suicide brains, 5-HT neurons are smaller in size and number (Underwood et al., 1999).

A decrease in 5-HT levels in the brain is thought to contribute to major depression (Anderson, 2004; Meltzer et al., 2003; Neumeister, 2003; Owens, 2004). The 5-HTT protein is believed to be directly related to the presence of 5-HT fibers, and in the brains of depressed patients there is a reduction in the both levels of 5-HTT (Malison et al., 1998) and 5-HTT-IR axons (Austin et al., 2002). Serotonin-specific reuptake inhibitors (SSRIs) have proved beneficial in a wide variety of affective disorders in addition to depression: panic disorder, obsessive-compulsive disorder, social phobia, and generalized anxiety disorder (Den Boer et al., 2000). All these affective disorders appear responsive to 5-HT dysfunction.

However, if homeostasis is lost, somatic and cognitive diseases, as well as affective disorders are impacted. There are several reports of an underlying disorder of the 5-HT system in neurological disorders: Pick's disease (Sparks and Markesbery, 1991), Parkinson's disease (Halliday et al., 1990; Menza et al., 1999), Alzheimer's disease (AD) (Marksteiner et al., 2003), ischemic heart disease (Stout et al., 2003), spongiform encephalopathies (Fraser et al., 2003), and diffuse Lewy body dementia (DLBD) (Ballard et al., 2002). In DLBD, Lewy bodies occur in the dorsal raphe nucleus (Langlais et al., 1993) and marked reductions of serotonin levels are reported in the striatum (Langlais et al., 1993), neocortex (Ohara et al., 1998), and frontal cortex (Perry et al., 1993). Major depression occurs in at least $30 \%$ of individuals suffering from DLBD (Klakta et al., 1996), with an association between the depressive disorder and reduced 5-HTT (Malison et al., 1998).

Neurological disorders all have separate causes and distinct characteristics which can be easily identified by the experienced clinician. Depression, the sign of a 5-HT dysfunction, is considered secondary to the primary neurological disease. This type of thinking is illustrated in the following passage from the seventh edition of "Adam's and Victor's Manual of Neurology." "Moreover, the anatomical substrate of the many diseases causing intellectual decline involve different parts of the cerebral cortex .... It is not surprising, therefore, that the dementing diseases may also cause a number of non-cognitive disturbances, such 
as loss of emotional control, changes in behavior and personality ..." (Victor and Ropper, 2002, p. 170). This implies the underlying pathology of the dementia and the noncognitive disturbances are the same.

However, if the dementing diseases are causing the affective symptoms, one would assume that cognitive problems would normally precede the noncognitive symptoms. But neurodegenerative disorders often exhibit affective symptoms as an initial presentation of the neurodegenerative disease (Kessing and Andersen, 2004), which can dominate the initial clinical presentation (Ballard et al., 2002). A history of major depression, without specification of episode-related cognitive impairment, appears to be a risk factor for subsequent onset of dementia (Kessing and Andersen, 2004). This is supported by early work with twins, which found that depression and psychiatric illness were risk factors for developing dementia (Wetherell et al., 1999). Depression is also known to be a risk factor for the onset of ADs (Chen et al., 1999; Green et al., 2003; Kokmen et al., 1991; Kral and Emery, 1989). Finally, psychiatric deficits may be improved by treatment, but impaired patients' cognitive functioning often does not completely normalize, especially in the areas of memory, executive function, and information-processing speed (Nebes et al., 2003).

Depression can have a neuropathological consequence. Dr. Varham Haroutunian and colleagues found that the brains of $\mathrm{AD}$ patients with a lifetime history of depression showed significantly higher levels of both plaque and tangle formation within the hippocampus than brains of $\mathrm{AD}$ patients without a lifetime history of depression (Rapp et al., 2006). This suggests that depression comorbid with $\mathrm{AD}$ may act synergistically, while comorbidity of DLBD with AD does not. Could the loss of 5-HT, associated with depression, be a key factor in brain deterioration? Many serotonin researchers over the last 50 years have argued for a larger, more global (holistic) function for serotonin. In unicellular organisms and plants, this may be related to regulation of oxidation. The same appears to be true in mammals (Munoz-Castaneda et al., 2006). These early functions of 5-HT can be envisioned to now include neuroplasticity which disrupts brain homeostasis. Clinically, the eventual result of this holistic dysfunction of the serotonin system is depression. 5-HT loss, associated with depression, leads to increases in the occurrence and severity of neurological disorders. The ultimate breakdown of brain homeostasis results in the destruction of many neurological networks, and in extreme cases, results in suicide, the ultimate rejection of life.

\section{References}

Ahlemeyer, B., Beier, H., Semkova, I., Schaper, C., and Krieglstein, J. (2000). S-100beta protects cultured neurons against glutamate- and staurosporine-induced damage and is involved in the antiapoptotic action of the 5 HT(1A)-receptor agonist, Bay x 3702. Brain Res. 858, 121-128. 
Alvarez-Buylla, A., García-Verdugo, J. M., and Tramonti, A. D. (2001). A unified hypothesis on the lineage of neural stem cells Nature. Neuroscience 2, 287-293.

Anderson, G. M. (2004). Peripheral and central neurochemical effects of the selective serotonin reuptake inhibitors (SSRIs) in humans and nonhuman primates: Assessing bioeffect and mechanisms of action. Int. F. Dev. Neurosci. 22, 397-404.

Angiolillo, P. J., and Vanderkooi, J. M. (1996). Hydrogen atoms are produced when tryptophan within a protein is irradiated with ultraviolet light. Photochem. Photobiol. 64, 492-495.

Austin, M. C., Whitehead, R. E., Edgar, C. L., Janosky, J. E., and Lewis, D. A. (2002). Localized decrease in serotonin transporter-immunoreactive axons in the prefrontal cortex of depressed subjects committing suicide. Neuroscience 114, 807-815.

Azmitia, E. C. (1978). The serotonin producing neurons of the midbrain median and dorsal raphe nuclei. In "The Handbook of Psycho-pharmacology" (L. L. Iversen, S. D. Iversen, and S. Snyder, Eds.), Vol. 9, pp. 233-314. Plenum Press, NY.

Azmitia, E. C. (1987). The primate serotonergic system: Progression towards a collaborative organization. In "Psychopharmacology. Third Generation of Progress" (H. Meltzer, Ed.), pp. 61-74. Plenum Press, NY.

Azmitia, E. C. (1999). Serotonin neurons, neuroplasticity, and homeostasis of neural tissue. Neuropsychopharmacology 21(2 Suppl.), 33S-45S.

Azmitia, E. C. (2001a). Modern views on an ancient chemical: Serotonin effects on cell proliferation, maturation, and apoptosis. Brain Res. Bull. 56, 413-424.

Azmitia, E. C. (2001b). Neuronal instability: Implications for Rett's syndrome. Brain Dev. 23(Suppl. 1), $\mathrm{S} 1-\mathrm{S} 10$.

Azmitia, E. C. (2002). Cajal's hypotheses on neurobiones and neurotropic factor match properties of microtubules and S-100 $\beta$. Progress in Brain Research 136, 87-100.

Azmitia, E. C. (2004). Serotoninergic chemoreceptive neurons: A search for a shared function viewpoint; American Society for Pharmacology and Experimental Therapeutics (ASPET). Mol. Intervent. 4, 18-21.

Azmitia, E. C., and Gannon, P. J. (1983). The ultrastructural localization of serotonin immunoreactivity in myelinated and unmyelinated axons within the medial forebrain bundle of rat and monkey. F. Neurosci. 3, 2083-2090.

Azmitia, E. C., and Gannon, P. J. (1986). The primate serotonergic system: A review of human and animal studies and a report on Macaca fascicularis. Adv. Neurol. 43, 407-468.

Azmitia, E. C., and Liao, B. (1994). Dexamethasone reverses adrenalectomy-induced neuronal dedifferentiation in midbrain raphe-hippocampus axis. Ann. NY Acad. Sci. 746, 180-193.

Azmitia, E. C., and Whitaker-Azmitia, P. M. (1987). Target cell stimulation of serotonergic neurons in primary dissociated tissue culture. Neuroscience 20, 47-63.

Azmitia, E. C., Murphy, R. B., and Whitaker-Azmitia, P. M. (1990). MDMA (ecstasy) effects on cultured serotonergic neurons: Evidence for $\mathrm{Ca}^{++}$dependent toxicity linked to release. Brain Res. 510, 97-103.

Azmitia, E. C., Liao, B., and Chen, Y. (1993). Increase of tryptophan hydroxylase enzyme protein by dexamethasone in adrenalectomized rat midbrain. F. Neurosci. 13, 5041-5055.

Azmitia, E. C., Rubinstein, V. J., Strafaci, J. A., Rios, J. C., and Whitaker-Azmitia, P. M. (1995). $5-\mathrm{HT}_{1 \mathrm{~A}}$ agonist and dexamethasone reversal of para-chloroamphetamine induced loss of MAP-2 and synaptophysin immunoreactivity in adult rat brain. Mol. Brain Res. 677, 181-192.

Ballard, C., Johnson, M., Piggott, M., Perry, R., O’Brien, J., Rowan, E., Perry, E., Lantos, P., Cairns, N., and Holmes, C. (2002). A positive association between 5HT re-uptake binding sites and depression in dementia with Lewy bodies. F. Affect. Disord. 69, 219-223.

Baudier, J., and Cole, R. D. (1988). Interactions between the microtubule-associated tau proteins and S100b regulate tau phosphorylation by the $\mathrm{Ca}^{2+} /$ calmodulin-dependent protein kinase II. 7. Biol. Chem. 263, 5876-5883. 
Bjorksten, K. S., Bjerregaard, P., and Kripke, D. F. (2005). Suicides in the midnight sun - a study of seasonality in suicides in West Greenland. Psychiatry Res. 133, 205-213.

Borkman, R. F., and Lerman, S. (1978). Fluorescence spectra of tryptophan residues in human and bovine lens proteins. Exp. Eye Res. 26, 705-713.

Boularand, S., Biguet, N. F., Vidal, B., Veron, M., Mallet, J., Vincent, J. D., Dufour, S., and Vernier, P. (1998). Tyrosine hydroxylase in the european eel (Anguilla anguilla): cDNA cloning, brain distribution, and phylogenetic analysis. F. Neurochem. 71, 460-470.

Boyle, J. P., and Yoshino, T. P. (2005). Serotonin-induced muscular activity in Schistosoma mansoni larval stages: Importance of 5-HT transport and role in daughter sporocyst production. 7. Parasitol. 91, 542-550.

Brodie, B. B., and Shore, P. A. (1957). A concept for a role of serotonin and norepinephrine as chemical mediators in the brain. Ann. NY Acad. Sci. 66, 631-642.

Cajal, S. R. y. (1899). "Texture of the Nervous System of Man and the Vertebrates." Translation by P. Pasik and T. Pasik (1999). Springer-Verlag, Wien, New York.

Cannon, W. B. (1929). Organization for physiological homeostasis. Physiol. Rev. 9, 399-431.

Chamas, F. M., Underwood, M. D., Arango, V., Serova, L., Kassir, S. A., Mann, J. J., and Sabban, E. L. (2004). Immobilization stress elevates tryptophan hydroxylase mRNA and protein in the rat raphe nuclei. Biol. Psychiatry 55, 278-283.

Chang, M. S., Ariah, L. M., Marks, A., and Azmitia, E. C. (2005). Chronic gliosis induced by loss of S-100B: Knockout mice have enhanced GFAP-immunoreactivity but blunted response to a serotonin challenge. Brain Res. 1031, 1-9.

Chao, M. Y., Komatsu, H., Fukuto, H. S., Dionne, H. M., and Hart, A. C. (2004). Feeding status and serotonin rapidly and reversibly modulate a Caenorhabditis elegans chemosensory circuit. Proc. Natl. Acad. Sci. USA 101, 15512-15517.

Chen, P., Ganguli, M., Mulsant, B. H., and DeKosky, S. T. (1999). The temporal relationship between depressive symptoms and dementia: A community-based prospective study. Arch. Gen. Psychiatry 56, 261-266.

Cordero, M. E., Rodríguez, A., Torres, R., and Valenzuela, C. Y. (2001). Human raphe magnus nucleus: A morphometric Golgi-Cox study with emphasis on sex differences. Brain Res. Dev. Brain Res. 131, 85-92.

Davila-Garcia, M. I., and Azmitia, E. C. (1990). Neuropeptides as positive or negative neuronal growth regulatory factors: Effects of ACTH and Leu-enkephalin on cultured serotonergic neurons. In "Molecular Aspects of Development and Aging of Nervous System" (J. M. Lauder, A. Privat, E. Giacobini, P. S. Timiras, and A. Vernadakis, Eds.), pp. 75-92. Plenum Press, New York.

Den Boer, J. A., Bosker, F. J., and Slaap, B. R. (2000). Serotonergic drugs in the treatment of depressive and anxiety disorders. Hum. Psychopharmacol. 15, 315-336.

Donato, R., Giambanco, I., and Aisa, M. C. (1989). Molecular interaction of S-100 proteins with microtubule proteins in vitro. F. Neurochem. 53, 566-571.

Dreyer, K. (1959). Comparative suicide statistics. II. Death rates from suicide in Denmark since 1921, and seasonal variations since 1835. Dan. Med. Bull. 6, 75-81.

Eckert, S. E., Hoffmann, B., Wanke, C., and Braus, G. H. (1999). Sexual development of Aspergillus nidulans in tryptophan auxotrophic strains. Arch. Microbiol. 172, 157-166.

Eriksen, J. L., and Druse, M. J. (2001). Astrocyte-mediated trophic support of developing serotonin neurons: Effects of ethanol, buspirone, and S100B. Brain Res. Dev. Brain Res. 131, 9-15.

Eriksen, J. L., Gillespie, R., and Druse, M. J. (2002). Effects of ethanol and 5-HT1A agonists on astroglial S100B. Brain Res. Dev. Brain Res. 139, 97-105.

Facchini, P. J., Huber-Allanach, K. L., and Tari, L. W. (2000). Plant aromatic L-amino acid decarboxylases: Evolution, biochemistry, regulation, and metabolic engineering applications. Phytochemistry 54, 121-138.

Fernstrom, J. D. (1977). Effects on the diet on brain neurotransmitters. Metabolism 26, 207-223. 
Fraser, E., McDonagh, A. M., Head, M., Bishop, M., Ironside, J. W., and Mann, D. M. (2003). Neuronal and astrocytic responses involving the serotonergic system in human spongiform encephalopathies. Neuropathol. Appl. Neurobiol. 29, 482-495.

Garattini, S., and Valzelli, L. (1965). "Serotonin." Elsevier Publishing Co., Amsterdam, London, New York.

Glanzman, D. L., Kandel, E. R., and Schacher, S. (1990). Target-dependent structural changes accompanying long-term synaptic facilitation in Aplysia neurons. Science 249, 799-802.

Green, R. C., Cupples, L. A., Kurz, A., Auerbach, S., Go, R., Sadovnick, D., Duara, R., Kukull, W. A., Chui, H., Edeki, T., Griffith, P. A., Friedland, R. P., et al. (2003). Depression as a risk factor for Alzheimer disease: The MIRAGE Study. Arch. Neurol. 60, 753-759.

Grenett, H. E., Ledley, F. D., Reed, L. L., and Woo, S. L. (1987). Full-length cDNA for rabbit tryptophan hydroxylase: Functional domains and evolution of aromatic amino acid hydroxylases. Proc. Natl. Acad. Sci. USA 84, 5530-5534.

Halliday, G. M., Blumbergs, P. G., Cotton, R. G., Blessing, W. W., and Geffen, L. B. (1990). Loss of brainstem serotonin- and substance P-containing neurons in Parkinson's disease. Brain Res. 510, 104-107.

Hendricks, T., Francis, N., Fyodorov, D., and Deneris, E. S. (1999). The ETS domain factor Pet-1 is an early and precise marker of central serotonin neurons and interacts with a conserved element in serotonergic genes. F. Neurosci. 19, 10348-10356.

Hess, W. R. (1954). "Das Zwischenhirn." Benno Schwabe, Basel.

Hillion, J., Milne-Edwards, J. B., Catelon, J., de Vitry, F., Gros, F., and Hamon, M. (1993). Prenatal developmental expression of rat brain 5-HT1A receptor gene followed by PCR. Biochem. Biophys. Res. Commun. 191, 991-997.

Hofmann, M. A., Drury, S., Fu, C., Qu, W., Taguchi, A., Lu, Y., Avila, C., Kambham, N., Bierhaus, A., Nawroth, P., Neurath, M. F., Slattery, T., et al. (1999). RAGE mediates a novel proinflammatory axis: A central cell surface receptor for S100/calgranulin polypeptides. Cell 97, 889-901.

Horen, W. P. (1972). Insect and scorpion sting. JAMA 221, 894-898.

Hsieh, H. L., Schafer, B. W., Weigle, B., and Heizmann, C. W. (2004). S100 protein translocation in response to extracellular S100 is mediated by receptor for advanced glycation endproducts in human endothelial cells. Biochem. Biophys. Res. Commun. 316, 949-959.

Ivanchenko, M. G., Coffeen, W. G., Lomax, T. L., and Dubrovsky, J. G. (2006). Mutations in the Diageotropica (Dgt) gene uncouple patterned cell division during lateral root initiation from proliferative cell division in the pericycle. Plant f. 46, 436-447.

Jacobs, B. L., and Azmitia, E. C. (1992). Structure and function of the brain serotonin system. Physiol. Rev. 72, 163-228.

Kessing, L. V., and Andersen, P. K. (2004). Does the risk of developing dementia increase with the number of episodes in patients with depressive disorder and in patients with bipolar disorder? 7. Neurol. Neurosurg. Psychiatry 75, 1662-1666.

Klakta, L. A., Louis, E. D., and Schiffer, R. B. (1996). Psychiatric features in diffuse Lewy body Disease: Findings in 28 pathologically diagnosed cases. Neurology 47, 1148-1152.

Kligman, D., and Marshak, D. R. (1985). Purification and characterization of a neurite extension factor from bovine brain. Proc. Natl. Acad. Sci. USA 82, 7136-7139.

Kokmen, E., Beard, C. M., Chandra, V., Offord, K. P., Schoenberg, B. S., and Ballard, D. J. (1991). Clinical risk factors for Alzheimer's disease: A population-based case-control study. Neurology 41, 1393-1397.

Kolar, J., and Machackova, I. (2005). Melatonin in higher plants: Occurrence and possible functions. 7. Pineal Res. 39, 333-341.

Kral, V. A., and Emery, O. B. (1989). Long-term follow-up of depressive pseudodementia of the aged. Can. F. Psychiatry 34, 445-446. 
Kravitz, E. A. (2000). Serotonin and aggression: Insights gained from a lobster model system and speculations on the role of amine neurons in a complex behavior. F. Comp. Physiol. [A] 186, 221-238.

Kristan, W. B., Jr., and Nusbaum, M. P. (1982). The dual role of serotonin in leech swimming. 7. Physiol. (Paris) 78, 743-747.

Langlais, P. J., Thal, L., Hansen, L., Galasko, D., Alford, M., and Masliah, E. (1993). Neurotransmitters in basal ganglia and cortex of Alzheimer's disease with and without Lewy bodies. Neurology 43, 1927-1934.

Lemaire, P. A., and Adosraku, R. K. (2002). An HPLC method for the direct assay of the serotonin precursor, 5-hydroxytrophan, in seeds of Griffonia simplicifolia. Phytochem. Anal. 13, 333-337.

Liao, B., Miesk, B. H., and Azmitia, E. C. (1993). Loss of 5-HT1A receptor mRNA in the dentate gyrus of the long-term adrenalectomized rat and rapid reversal by dexamethasone. Mol. Brain Res. 19, 328-332.

Lidov, H. G. W., and Molliver, M. E. (1982). An immunohistochemical study of serotonin neuron development in the rat: Ascending pathways and terminal fields. Brain Res. Bull. 8, 389-430.

Liu, C. N., and Chambers, W. W. (1958). Intraspinal sprouting of dorsal root ganglia axons. Arch. Neurol. Psychiatry 79, 46-61.

Malison, R. T., Price, L. H., Berman, R., van Dyck, C. H., Pelton, G. H., Carpenter, L., Sanacora, G., Owens, M. J., Nemeroff, C. B., Rajeevan, N., Baldwin, R. M., Seibyl, J. P., et al. (1998). Reduced brain serotonin transporter availability in major depression as measured by [123I]-2 beta-carbomethoxy-3 beta-(4-iodophenyl)tropane and single photon emission computed tomography. Biol. Psychiatry 44, 1090-1098.

Marksteiner, J., Walch, T., Bodner, T., Gurka, P., and Donnemiller, E. (2003). Fluoxetine in Alzheimer's disease with severe obsessive compulsive symptoms and a low density of serotonin transporter sites. Pharmacopsychiatry 36, 207-209.

Marois, R., and Carew, T. J. (1997). Ontogeny of serotonergic neurons in Aplysia californica. F. Comp. Neurol. 386, 477-490.

Martin-Cora, F. J., Fornal, C. A., Metzler, C. W., and Jacobs, B. L. (2002). Insulin-induced hypoglycemia decreases single-unit activity of serotonergic medullary raphe neurons in freely moving cats: Relationship to sympathetic and motor output. Eur. F. Neurosci. 16, 722-734.

Matsukawa, M., Ogawa, M., Nakadate, K., Maeshima, T., Ichitani, Y., Kawai, N., and Okado, N. (1997). Serotonin and acetylcholine are crucial to maintain hippocampal synapses and memory acquisition in rats. Neurosci. Lett. 230, 13-16.

Matthiessen, L., Daval, G., Bailly, Y., Gozlan, H., Hamon, M., and Verge, D. (1992). Quantification of 5-hydroxytryptamine $1 \mathrm{~A}$ receptors in cerebellum of normal and X-irradiated rats during postnatal development. Neuroscience 51, 475-485.

Mazer, C., Muneyyirci, J., Taheny, K., Raio, N., Borella, A., and Whitaker-Azmitia, P. (1997). Serotonin depletion during synaptogenesis leads to decreased synaptic density and learning deficits in the adult rat: A possible model of neurodevelopmental disorders with cognitive deficits. Brain Res. 760, 68-73.

McCauley, D. W. (1997). Serotonin plays an early role in the metamorphosis of the hydrozoan Phialidium gregarium. Dev. Biol. 190, 229-240.

Meltzer, H. Y., Perry, E., and Jayathilake, K. (2003). Clozapine-induced weight gain predicts improvement in psychopathology. Schizophr. Res. 59, 19-27.

Menza, M. A., Palermo, B., DiPaola, R., Sage, J. I., and Ricketts, M. H. (1999). Depression and anxiety in Parkinson's disease: Possible effect of genetic variation in the serotonin transporter. 7. Geriatr. Psychiatry Neurol. 12, 49-52.

Moss, B. L., Fuller, A. D., Sahley, C. L., and Burrell, B. D. (2005). Serotonin modulates axo-axonal coupling between neurons critical for learning in the leech. F. Neurophysiol. 94, 2575-2589. 
Munoz-Castaneda, J. R., Montilla, P., Padillo, F. J., Bujalance, I., Munoz, M. C., Muntane, J., and Tunez, I. (2006). Role of serotonin in cerebral oxidative stress in rats. Acta Neurobiol. Exp. (Wars.) 66, $1-6$.

Nebes, R. D., Pollock, B. G., Houck, P. R., Butters, M. A., Mulsant, B. H., Zmuda, M. D., and Reynolds, C. F., III (2003). Persistence of cognitive impairment in geriatric patients following antidepressant treatment: A randomized, double-blind clinical trial with nortriptyline and paroxetine. F. Psychiatr. Res. 37, 99-108.

Neumeister, A. (2003). Tryptophan depletion, serotonin, and depression: Where do we stand? Psychopharmacol. Bull. 37, 99-115.

Nishi, M., Kawata, M., and Azmitia, E. C. (2000). Trophic interactions between brain-derived neurotrophic factor and sl00beta on cultured serotonergic neurons. Brain Res. 868, 113-118.

Ohara, K., Kondo, N., and Ohara, K. (1998). Changes of monoamines in post-mortem brains from patients with diffuse Lewy body disease. Prog. Neuropsychopharmacol. Biol. Psychiatry 22, 311-317.

Okado, N., Cheng, L., Tanatsugu, Y., Hamada, S., and Hamaguchi, K. (1993). Synaptic loss following removal of serotoninergic fibers in newly hatched and adult chickens. F. Neurobiol. 24, 687-698.

Owens, M. J. (2004). Selectivity of antidepressants: From the monoamine hypothesis of depression to the SSRI revolution and beyond. F. Clin. Psychiatry 65(Suppl. 4), 5-10.

Parent, A. (1981). Comparative anatomy of the serotoninergic systems. F. Physiol. (Paris) 77, 147-156.

Pasternak, T., Potters, G., Caubergs, R., and Jansen, M. A. (2005). Complementary interactions between oxidative stress and auxins control plant growth responses at plant, organ, and cellular level. F. Exp. Bot. 56, 1991-2001.

Peroutka, S. J., and Howell, T. A. (1994). The molecular evolution of G protein-coupled receptors: Focus on 5-hydroxytryptamine receptors. Neuropharmacology 33, 319-324.

Perry, E. K., Marshall, E., Thompson, P., McKeith, I. G., Collerton, D., Fairbairn, A. F., Ferrier, I. N., Irving, D., and Perry, R. H. (1993). Monoaminergic activities in Lewy body dementia: Relation to hallucinosis and extrapyramidal features. F. Neural. Transm. 6, 167-177.

Pettigrew, D. B., Smolen, P., Baxter, D. A., and Byrne, J. H. (2005). Dynamic properties of regulatory motifs associated with induction of three temporal domains of memory in aplysia. F. Comput. Neurosci. 18, 163-181.

Rapp, M. A., Schnaider-Beeri, M., Grossman, H. T., Sano, M., Perl, D. P., Purohit, D. P., Gorman, J. M., and Haroutunian, V. (2006). Increased hippocampal plaques and tangles in patients with Alzheimer disease with a lifetime history of major depression. Arch. Gen. Psychiatry 63, 161-167.

Rong, L. L., Gooch, C., Szabolcs, M., Herold, K. C., Lalla, E., Hays, A. P., Yan, S. F., Yan, S. S., and Schmidt, A. M. (2005). RAGE: A journey from the complications of diabetes to disorders of the nervous system - striking a fine balance between injury and repair. Restor. Neurol. Neurosci. 23, $355-365$.

Salmoun, M., Devijver, C., Daloze, D., Braekman, J. C., and van Soest, R. W. (2002). 5-Hydroxytryptamine-derived alkaloids from two marine sponges of the genus Hyrtios. F. Nat. Prod. 65, 1173-1176.

Scheibel, M. S., Tomiyasu, U., and Scheibek, A. B. (1975). Do raphe nuclei of the reticular formation have a neuroscretory or vascular sensor function? Exp. Neurol. 47, 316-329.

Scott, M. M., Krueger, K. C., and Deneris, E. S. (2005). A differentially autoregulated Pet-1 enhancer region is a critical target of the transcriptional cascade that governs serotonin neuron development. F. Neurosci. 25, 2628-2636.

Selye, H. (1956). "The Stress of Life." McGraw-Hill Book Co., Inc., New York, Toronto, London.

Severson, C. A., Wang, W., Pieribone, V. A., Dohle, C. I., and Richerson, G. B. (2003). Midbrain serotoninergic neurons are central pH chemoreceptors. Nat. Neurosci. 6, 1139-1140. 
Sheu, F. S., Azmitia, E. C., Marshak, D. R., Parker, P. J., and Routtenberg, A. (1994). Glial-derived S100b protein selectively inhibits recombinant beta protein kinase $\mathrm{C}(\mathrm{PKC})$ phosphorylation of neuron-specific protein F1/GAP43. Brain Res. Mol. Brain Res. 21, 62-66.

Singh, I. (1964). Seasonal variations in the nature of neurotransmitters in a frog vagus-stomach muscle preparation. Arch. Int. Physiol. Biochim. 72, 843-851.

Smith, B. N. (1976). Evolution of C4 photosynthesis in response to changes in carbon and oxygen concentrations in the atmosphere through time. Biosystems 8, 24-32.

Sparks, D. L., and Markesbery, W. R. (1991). Altered serotonergic and cholinergic synaptic markers in Pick's disease. Arch. Neurol. 48, 796-799.

Sparks, D. L., and Slevin, J. T. (1985). Determination of tyrosine, tryptophan and their metabolic derivatives by liquid chromatography-electrochemical detection: Application to post mortem samples from patients with Parkinson's and Alzheimer's disease. Life Sci. 36, 449-457.

Steinbusch, H. W. M. (1981). Distribution of serotonin-immunoreactivity in the central nervous system of the rat-cell bodies and terminals. Neuroscience 4, 557-618.

Stout, S. S., Somerset, W. I., Miller, A., and Musselman, D. L. (2003). Paroxetine use in medically ill patients. Psychopharmacol. Bull. 37, 108-122.

Tork, I. (1990). Anatomy of the Serotonin System. Ann. NY Acad. Sci. 600, 9-36.

Trulson, M. E., and Jacobs, B. L. (1979). Raphe unit activity in freely moving cats: Correlation with level of behavioral arousal. Brain Res. 163, 135-150.

Underwood, M. D., Khaibulina, A. A., Ellis, S. P., Moran, A., Rice, P. M., Mann, J. J., and Arango, V. (1999). Morphometry of the dorsal raphe nucleus serotonergic neurons in suicide victims. Biol. Psychiatry 46, 473-483.

Victor, M., and Ropper, A. H. (2002). "Adam's and Victor's Manual of Neurology," 7th ed. McGraw-Hill, NY.

Wallace, J. A., and Lauder, J. M. (1983). Development of the serotonergic system in the rat embryo: An immunocytochemical study. Brain Res. Bull. 10, 459-479.

Weiger, W. A. (1997). Serotonergic modulation of behaviour: A phylogenetic overview. Biol. Rev. Camb. Philos. Soc. 72, 61-95.

Wetherell, J. L., Gatz, M., Johansson, B., and Pedersen, N. L. (1999). History of depression and other psychiatric illness as risk factors for Alzheimer disease in a twin sample. Alzheimer Dis. Assoc. Disord. 13, 47-52.

Whitaker-Azmitia, P. M. (1999). The discovery of serotonin and its role in neuroscience. Neuropsychopharmacology $\mathbf{2 1}(2 \mathrm{~S}), 2 \mathrm{~S}-8 \mathrm{~S}$.

Whitaker-Azmitia, P. M. (2005). Behavioral and cellular consequences of increasing serotonergic activity during brain development: A role in autism? Int. F. Dev. Neurosci. 23, 75-83.

Whitaker-Azmitia, P. M., Murphy, R. B., and Azmitia, E. C. (1990). S-100 protein release from astrocytic glial cells by stimulation of 5-HT1A receptors and regulates the development of serotonergic neurons. Brain Res. 528, 155-158.

Whitaker-Azmitia, P. M., Clarke, C., and Azmitia, E. C. (1993). Localization of 5-HT-1A receptors to astroglial cells in adult rats. Synapse 14, 201-205.

Whitaker-Azmitia, P. M., Borella, A., and Raio, N. (1995). Serotonin depletion in the adult rat causes loss of the dendritic marker MAP-2. A new animal model of schizophrenia? Neuropsychopharmacology 12, 269-272.

Wiens, M., Koziol, C., Batel, R., and Muller, W. E. (1998). Phenylalanine hydroxylase from the sponge Geodia cydonium: Implication for allorecognition and evolution of aromatic amino acid hydroxylases. Dev. Comp. Immunol. 22, 469-478.

Wikgren, M. C., and Reuter, M. (1985). Neuropeptides in a microturbellarian-whole mount immunocytochemistry. Peptides 6(Suppl. 3), 471-475. 
Wilmanns, M., Hyde, C. C., Davies, D. R., Kirschner, K., and Jansonius, J. N. (1991). Structural conservation in parallel beta/alpha-barrel enzymes that catalyze three sequential reactions in the pathway of tryptophan biosynthesis. Biochemistry 30, 9161-9169.

Wilson, C. C., Faber, K. M., and Haring, J. H. (1998). Serotonin regulates synaptic connections in the dentate molecular layer of adult rats via 5-HTla receptors: Evidence for a glial mechanism. Brain Res. 782, 235-239.

Wirz-Justice, A., Lichtsteiner, M., and Feer, H. (1977). Diurnal and seasonal variations in human platelet serotonin in man. F. Neural Transm. 41, 7-15.

Woolley, D. W. (1961). "The Biochemical Basis of Psychosis." John Wiley and Sons, Inc, New York, NY.

Yaguchi, S., and Katow, H. (2003). Expression of tryptophan 5-hydroxylase gene during sea urchin neurogenesis and role of serotonergic nervous system in larval behavior. f. Comp. Neurol. 466, 219-229.

Zhao, J., and Last, R. L. (1996). Coordinate regulation of the tryptophan biosynthetic pathway and indolic phytoalexin accumulation in Arabidopsis. Plant Cell 8, 2235-2244. 